\title{
THE USE OF MYTHOLOGICAL AND RELIGIOUS SYMBOLS IN THE TERRITORIAL MARKETING OF THE BLACK SEA COUNTRIES
}

\author{
(C) Yulia P. Ten \\ Financial University under the Government of the Russian Federation, \\ Moscow, Russian Federation \\ YPTen@fa.ru
}

The article develops a symbolic-value approach to the analysis of branding in territorial marketing. The purpose of the study is to analyze the construction of the Black Sea region brand based on the appeal to mythological and religious symbols of past cultural eras in the history of this territory. A semiotic approach is used to analyze the problem of territory branding. The author considers the brand as a complex symbolic structure that narrows the territory as an intangible asset. It has been revealed that the cultural heritage of the Black Sea region ancient civilizations, especially mythology and religion, is the main one in formation of a positive image of this territory. The idea is substantiated that ancient mythological and religious symbols are important elements in the construction of the Black Sea region collective identity. It is recommended to refer to ancient symbols in developing a strategy for promoting the Black Sea territory brand. If ancient symbols acquire new, more modern meanings for interpretation by consumers, the brand of the territory will eventually become more competitive.

Key words: territorial marketing, territory brand, Black Sea region territorial marketing, mythological and religious symbols.

\section{[Ю.П. Тен Использование мифологических и религиозных символов в территориальном мар- кетинге стран Причерноморья]}

В статье развивается символико-ценностный подход к анализу брендинга в территориальном маркетинге. Целью исследования выступает анализ конструирования бренда Причерноморского региона на основе обращения к мифологическим и религиозным символам прошлых культурных эпох в истории данной территории. Используется семиотический подход к анализу проблемы брендирования территории. Автор рассматривает бренд как сложную знаково-символическую конструкцию, сужающую нематериальным активом территории. Выявлено, что культурное наследие древних цивилизаций Причерноморья, прежде всего мифологии и религии, является основным в формировании позитивного имиджа данной территории. Обосновывается мысль, что древние мифологические и религиозные символы выступают важными элементами в конструировании коллективной идентичности Причерноморья. При разработке стратегии продвижения бренда Причерноморской территории рекомендовано обращение к древним символам. Если древние символы получат новые, более современные, значения для интерпретации потребителями, то бренд территории со временем станет более конкурентоспособным.

Ключевые слова: территориальный маркетинг, бренд территории, территориальный маркетинг Причерноморья, мифологические и религиозные символы.

Yulia P. Ten - Ph.D. (Advanced Doctorate) in Philosophy, Associate Professor, Management department, Financial University under the Government of the Russian Federation, Moscow, Russian Federation.

Тен Юлия Павловна - доктор фрилософрских наук, доцент, Департамент менеджмента, Финансовый университет при Правительстве Российской Федерации, г. Москва, Российская Федерация.

The Black Sea region is one of the most attractive regions in terms of the tourist cluster. In the modern period, when the need for each country's national tourism development is actualized, the revival of entrepreneurial interest in ancient cultures and civilizations of the past is a completely expedient strategic task for developing the concept of territorial 
marketing of this region. The fact is that for almost three millennia, the Black Sea region has been a space for the birth, prosperity and decline of various cultures - ancient Scythians, Sarmatians, Cimmerians, Greeks, Romans, Alans, Slavs, Bulgars, etc. It is no coincidence that the Russian thinker Y.A. Zhdanov called the Caucasus the "solar plexus of Eurasia". Russian marketers should pay attention to the disclosure of the potential of this region based on the appeal to symbols as the most ancient social technologies for transmitting information in symbolic and semantic form.

From the author's point of view, the most attractive way to develop tourism marketing is to use ancient mythological and religious symbols in cross-cultural marketing communications. Hence, the aim of the study is to analyze the construction of the black sea region's brand on the basis of appealing to the mythological and religious symbols of past cultural eras in the history of the territory. The author turns to a semiotic approach to the problem of brand construction in territorial marketing.

Brand is a key element of marketing communications. A brand is a "cluster of strategic cultural ideas" [5]. A brand is an intangible asset of a territory. A brand is a verbal and non-verbal means of a territory, which lays the foundation for its future development. Branding will be assessed as effective if it creates unique and positive associations among consumers according to the positioning of a particular territory. Associations with a brand include its recognition, attitude to the brand, brand image and its individuality. Therefore, the most important brand value is a set of certain associations that form the value sense of a given brand, perceived and shared by consumers. Consumers value brand value only if it meets specific needs that are relevant to them [2].

From the point of view of the value-symbolic approach, a brand is a sign-symbolic system. If a brand has the ability to express not only information to the recipient, but also to influence emotions and hurt feelings, then the brand will become an axial strategic asset that can potentially bring significant profit to the branding object. Therefore, from the author's point of view, semiotic research should aid for the development of technologies for managing brand capital of a territory, since brands have sign systems that promote profitability, distinguishing their brands, differentiating them from competitors and involving consumers in the world of this brand. For example, the island state of Cyprus has a very attractive brand image, since the marketing strategy of positioning this territory is closely related to the symbols of cultural and Christian heritage.

In the international consumer culture, brands acquire a kind of mythological and religious symbols. The brand begins to acquire the mythical meanings of the totem by acting on the hidden unconscious layers of the psyche. This, in fact, forms the "brand communities". Interestingly, that the brand community can refer to individuals and social groups that have "common interests in certain brands and form a social universe constructed on myths, values, rituals, language and hierarchy" [4, p.1089]. Brand communities offer their representatives a certain experience and culture with norms, rituals, traditions and expectations [7, p.4]. Examples of brand communities are the Samsung community, McDonald's community, etc.

The symbol is a key characteristic of the brand community in contrast to other groups in terms of forming a brand through symbolic capital, implying a set of ideals, values, beliefs, practices, and other communication models. "A brand, as a symbol, creates a special dynamic in brand communities, which is separated from the logic of production and moves to the logic of consumption" [8, p.506]. Brands, as multi-digit symbolic constructs, become collective resources and "repositories of meaning" as well as references of identity [3]. In brand communities, a brand occupies a strategic point in marketing communications: ".... If a brand disappears, then collectivity will also disappear" [8, p.497]. It is no coincidence 
that the branding of Cyprus contains images from the ancient eras of the country culture, but which serve as a kind of markers of the identity of this territory.

In this way, brands are viewed as socio-cultural symbols through which consumers express their idea of collective identity, and in which meanings are expressed in the context of specific local, national or global discourses [9]. At the same time, brands are both symbols of ideals and values of consumer culture [6]. Thus, the brand is the carrier of the symbolic territory "capital", it is a design that is able to accommodate different systems of values. For example, the symbol of Prometheus is recognizable not only in Russia, but also abroad. As a result of cross-cultural marketing communications, recipients can either correctly "read" the meaning of the brand, or may not interpret it properly, as the sender of the message (the brand creator) would like. In this example, thanks to the dramatic poem "Prometheus-Chained" by the ancient Greek poet Aeschylus, a stable association with the habitat of this ancient titan was fixed for the Caucasus.

It is important to note that under the influence of globalization, a new universe of global consumer culture is being formed, in which brands are gradually acquiring recognition due to generally accepted meanings, as well as value associations that they evoke in most consumers. For example, Crimea peninsula is associated not only with the ancient civilizations of the ancient world, but also with Christianity. According to legend, the Apostle Andrew the First-Called delivered sermons here. So, according to legend, the sacrament of the Baptism of Prince Vladimir in the X century was carried out in the Crimea. The corresponding monuments and temple structures serve as the basis for branding this area.

The method of modeling the Black Sea region brand by means of symbols is especially interesting for international and national marketing in a situation where marketers are faced with the problem of meeting the needs and demands of customers who are focused in their consumer interests on the purchase of goods or services associated in the mass consciousness with certain symbols of a given region or country. The choice of goods and services that most fully expresses the symbolic system ideological and semantic field of the territory marketing historical socio-cultural environment can be especially effective. In this case, when reviving ancient symbols, marketers should understand that in the context of the modern worldview, it is necessary to give them a new modern layer of significations and meanings. For example, the Caucasus is the venue for the 2014 Winter Olympics, World Cup 2018.

The territory brand is one of the key factors of perception and evaluation of a particular region, formed on the basis of a territory positive image and is a manifestation of sensory and emotional consumer preferences, aimed at building a territory rating by creating additional competitive advantages. The Black Sea region brand should be presented as a combination of those ideas, knowledge and values that reflect the original consumer characteristics of this territory, which have received public recognition and fame, and are in stable demand among both national and foreign consumers.

In conclusion, it should be noted that a successful state brand can not only improve the domestic political image of the black sea region, but also increase the prestige of Russia as a whole, increase the volume of exports of branded goods, stimulate feelings of national identity, and increase the overall competitiveness of the country [1].

Brands are one of the most important tools in the arsenal of competition. Thoughtful brand positioning gives the country a competitive advantage over other countries. Positioning a territory through symbolic value branding has enormous potential for a region, especially in cases where stereotypes about a given territory lag behind modern realities.

In conclusion, globalization implies that countries and regions compete with each other to attract the attention, respect, and trust of investors, tourists, consumers, entrepreneurs, migrants, and the media. In this context, the positive brand of the black sea region 
provides a decisive competitive advantage not only for this region, but also for Russia as a whole.

\section{Лumepamypa}

1. Тюкаркина О.М. Роль национального брендинга при формировании внешнеполитического имиджа современной России. Диссертация...кандидата политических наук. М., 2012.

2. Aaker J. L., Benet-Martinez V., Garolera J. Consumption symbols as carriers of culture: a study of Japanese and Spanish brand personality constructs // Journal of Personality and Social Psychology. Vol. 81 (3). 2001.

3. Cohen A.P. The Symbolic construction of community. N.-Y.: Tavistock Publications, 1985.

4. Cova B. \& Pace S. Brand community of convenience products: new forms of customer empowerment: The case «my Nutella Community» // European Journal of Marketing. № 40. 2006. P. 1089.

5. Grant J. The brand innovation manifesto. L.: John Wiley \& Sons, 2006.

6. Holt $D$. How brands become icons: the principles of cultural branding. Boston: Harvard Business School Press, 2004.

7. Muniz A., O'Guinn T. Brand community // Journal of Consumer Research № 27. P. 4.

8. Stratton G., Northcote J. When totems beget clans: the brand symbol as the defining marker of brand communities // Journal of consumer culture. Vol. 16 (2). 2016. P. 506.

9. Torelli C.J., Stoner J.L. Managing cultural equity: a theoretical framework for building iconic brands in globalized markets // Brand Meaning Management / Eds. by D. J. Macinnis, C.W. Park. V. 12. L.: Emerald Publishing Limited, 2015.

\section{References}

1. Tyukarkina O.M. Rol natsionalnogo brendinga pri formirovanii vneshnepoliticheskogo imidzha sovremennoy Rossii. Dissertatsiya [...] kandidata politicheskikh nauk. [The role of national branding in the formation of the foreign policy image of modern Russia. Thesis for a Candidate Degree]. Moscow, 2012 (In Russian).

2. Aaker J. L., Benet-Martinez V., Garolera J. Consumption symbols as carriers of culture: a study of Japanese and Spanish brand personality constructs. Journal of Personality and Social Psychology. V. 81 (3). 2001.

3. Cohen A.P. The Symbolic construction of community. New York: Tavistock Publications, 1985.

4. Cova B. \& Pace S. Brand community of convenience products: new forms of customer empowerment: The case «my Nutella Community». European Journal of Marketing. No. 40. 2006. 1089 p.

5. Grant J. The brand innovation manifesto. London: John Wiley \& Sons, 2006.

6. Holt $D$. How brands become icons: the principles of cultural branding. Boston: Harvard Business School Press, 2004.

7. Muniz A., O'Guinn T. Brand community. Journal of Consumer Research No. 27. 4 p. 
8. Stratton G., Northcote J. When totems beget clans: the brand symbol as the defining marker of brand communities. Journal of consumer culture. V.16 (2). 2016. 506 p.

9. Torelli C.J., Stoner J.L. Managing cultural equity: a theoretical framework for building iconic brands in globalized markets. Brand Meaning Management. Eds. by D. J. Macinnis, C.W. Park. V. 12. London: Emerald Publishing Limited, 2015. 